\title{
An unusual cause of neonatal respiratory distress
}

\author{
Eve Smith,' Ramesh Kumar, ${ }^{1}$ Ruth Barron, ${ }^{1}$ Derek Bosman² \\ ${ }^{1}$ Department of Paediatrics, James Cook University Hospital, Middlesbrough, UK \\ ${ }^{2}$ Department of ENT, James Cook University Hospital, Middlesbrough, UK
}

Correspondence to Eve Smith, evemdsmith@yahoo.co.uk

\section{DESCRIPTION}

Three-week-old female presented with history of choking, crying, respiratory distress with feeds and associated failure to regain birth weight. On examination she had significant respiratory distress with tachypnoea and marked subcostal/ intercostal recession. Oxygen saturations were initially $95 \%$ in air but dropped to $69 \%$ when feeding.

Shortly after admission the patient developed sudden acute upper airway obstruction requiring emergency oral intubation and ventilation. A nasogastric tube was sited, passing easily through the right nostril but not the left. A CT scan undertaken to delineate nasal anatomy showed nasal inlet stenosis due to medialisation of the nasal processes of the maxilla at the inlet of the nose (figure 1). A diagnosis of congenital nasal pyriform aperture stenosis (CNPAS) was made and subsequent closer inspection of CT images showed the presence of an associated unerupted central upper frontal mega-incisor tooth (figure 2).

CNPAS is rare and should be distinguished from other causes of nasal airway obstruction such as choanal stenosis/ atresia. Definitive diagnosis is made by CT, with pyriform aperture width of $<11 \mathrm{~mm}$ being considered diagnostic in term infants. ${ }^{1}$ CNPAS can occur in isolation or be associated with holoprosencephaly, ocular coloboma, pituitary deficiency, a central mega-incisor, clinodactyly, hypoterorism, cleft palate or chromosomal abnormalities. ${ }^{2}$ Management

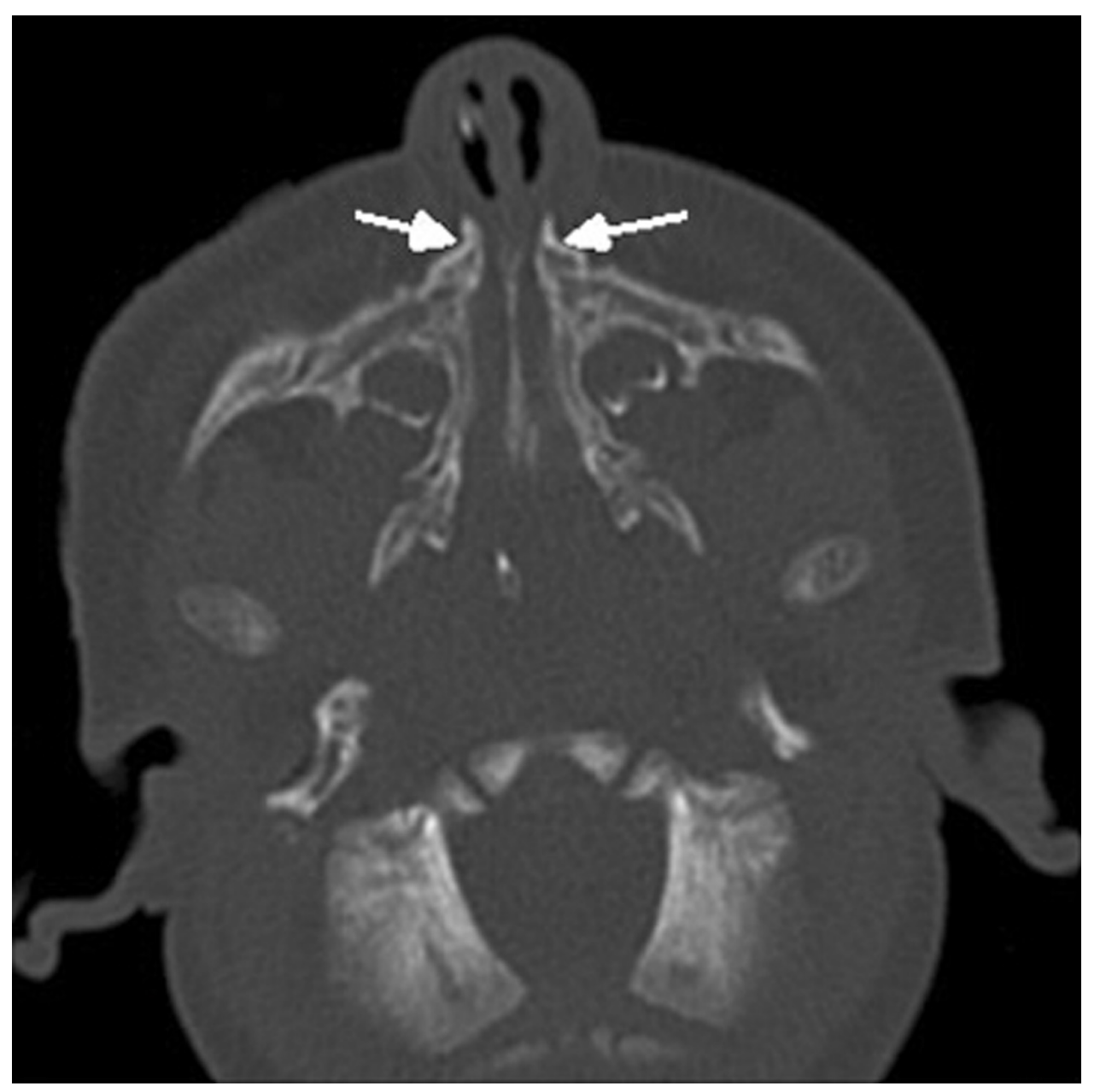

Figure 1 CT scan showing nasal pyriform aperture stenosis measuring $5 \mathrm{~mm}$ between the nasal processes of the maxilla (arrows). 


\section{BMJ Case Reports}

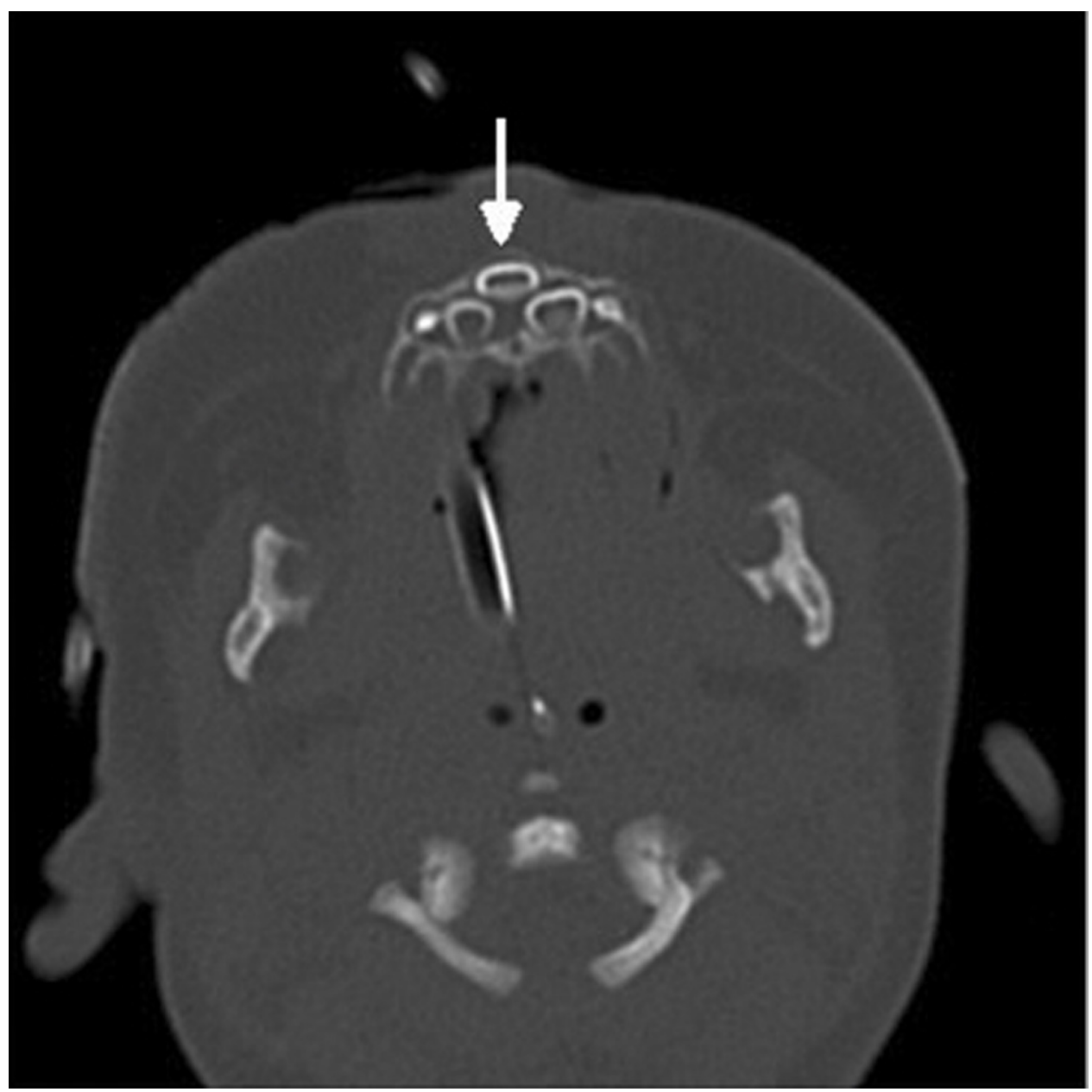

Figure 2 CT scan showing central frontal mega-incisor tooth (arrow).

can be conservative or involve surgical enlargement and temporary stenting. ${ }^{1}$

\section{Competing interests None.}

Patient consent Obtained.

\section{REFERENCES}

1. Losken A, Burstein FD, Williams JK. Congenital nasal pyriform aperture stenosis: diagnosis and treatment. Plast Reconstr Surg 2002;109:1506-11; discussion 1512.

2. Lo FS, Lee YJ, Lin SP, et al. Solitary maxillary central incisor and congenital nasal pyriform aperture stenosis. Eur J Pediatr 1998;157:39-44.

\footnotetext{
This pdf has been created automatically from the final edited text and images.

Copyright 2010 BMJ Publishing Group. All rights reserved. For permission to reuse any of this content visit http://group.bmj.com/group/rights-licensing/permissions.

BMJ Case Report Fellows may re-use this article for personal use and teaching without any further permission.

Please cite this article as follows (you will need to access the article online to obtain the date of publication) publication

Become a Fellow of BMJ Case Reports today and you can:

- Submit as many cases as you like

- Enjoy fast sympathetic peer review and rapid publication of accepted articles

- Access all the published articles

- Re-use any of the published material for personal use and teaching without further permission

For information on Institutional Fellowships contact consortiasales@bmjgroup.com

Visit casereports.bmj.com for more articles like this and to become a Fellow
}

Smith E, Kumar R, Barron R, Bosman D. An unusual cause of neonatal respiratory distress. BMJ Case Reports 2010;10.1136/bcr.05.2010.3022, date of 